\title{
Peramalan Stock Barang Dagangan Menggunakan Metode Single Exponential Smoothing
}

\author{
Saiful Nur Budiman
}

Universitas Islam Balitar, Indonesia

\begin{tabular}{|c|c|}
\hline Article Info & ABSTRACT \\
\hline Article History & $\begin{array}{l}\text { Forecasting can be used in any field which requires a prediction } \\
\text { of the existence of data in the future. Forecasting can be applied }\end{array}$ \\
\hline Received: $12-11-2021$ & of them to help budget sales for the next period. Time series data \\
\hline Revised : $17-11-2021$ & obtained from sales data during a certain period of sales of a \\
\hline Accpeted: $22-11-2021$ & $\begin{array}{l}\text { product can be used as the basis for forecasting. Excessive } \\
\text { restocking of goods is not good for a store, because there is a } \\
\text { possibility that the purchased goods will not sell well in the }\end{array}$ \\
\hline$\underline{\text { Keywords }}$ & future. There needs to be a good control process for restocking \\
\hline Forecasting; & goods, one of which can be used is to use a prediction of \\
\hline Single exponential & merchandise restocks using single exponential smoothing (SES). \\
\hline smoothing; & There are two kinds of sales data used, namely Koi Rice with a \\
\hline Time series. & $\begin{array}{l}\text { size of } 5 \mathrm{~kg} \text { and Bimoli Oil with a size of } 900 \mathrm{ml} \text {. From the } \\
\text { results of the SES calculation, a good alpha value for forecasting }\end{array}$ \\
\hline & $5 \mathrm{~kg}$ Koi Rice is 0.46 . While the alpha value for $900 \mathrm{ml}$ Bimoli \\
\hline$\square$ Corresponding Author & Oil is 0.704 . The alpha value is obtained from the calculation of \\
\hline Saiful Nur Budiman, & the smallest MSE value. The prediction results show that in the \\
\hline Universitas Islam Balitar, & eriod (15-30 September 2021) there will be a decrease in \\
\hline Tel. +62 85731644664 & f sales of goods from the two products, so that shop \\
\hline sync.saifulnb@gmail. & educe their shopping allotment. \\
\hline
\end{tabular}

\section{PENDAHULUAN}

Pentingnya manajemen kontrol pada sebuah pertokoan memberikan kemudahan pada pemilik toko untuk mengelola stock barang serta kontrol keuangan. Kegiatan melakukan perhitungan persediaan stock barang di gudang disebut juga stock opname. Pemeriksaan dan perhitungan barang di gudang secara langsung sangatlah menyita waktu. Jika stock kurang maka kebutuhan berikutnya akan berdampak pula, namun jika stock berlebih dan barang tidak kunjung laku malah menyebabkan rugi. Diperlukan sebuah metode yang mampu meramalkan atau memprediksi stock kebutuhan barang di masa mendatang, sehingga keuangan bisa dikontrol dengan baik.

Manfaat dari peramalan atau forecasting bisa terlihat dari pengambilan keputusan. Suatu keputusan yang baik merupakan keputusan yang didasarkan atas pertimbangan dari periode sebelumnya. Salah satu tujuan forecasting yang tekait dengan bisnis adalah meningkatkan efektivitas suatu rencana bisnis. Forecast penjualan menjadi dasar untuk penyusunan anggaran penjualan, yang mana ada beberapa teknik bisa digunakan untuk menyusun forecast penjualan ini antara lain pendapatan konsumen, pendapatan salesman, pendapatan sales manager, pendapatan para ahli. Data time series menunjukkan data berdasarkan urutan waktu. Waktu yang digunakan bisa berupa jam, harian, mingguan, dua mingguan, bulanan, tahunan. Data berkala digunakan untuk mendeskripsikan perkembangan suatu kegiatan atau keadaan selama selang waktu tertentu. Contoh data berkala antara lain jumlah produksi minyak per bulan, pertumbuhan ekonomi negara, indeks harga saham, indeks kurs dolar terhadap rupiah. 
Data time series ini bisa digunakan juga untuk meramalkan jumlah produksi barang yang terjadi di masa mendatang dengan cara menghitungnya dari masa lalu. Berdasarkan tekniknya, metode peramalan dibedakan berdasarkan kategori model kualitatif dan kuantitatif. Single exponential smoothing (SES) melakukan forecasting dengan melakukan rerataan nilai dari masa lala melalui runtut waktu dengan cara menurun. Ciri utama metode SES adalah data yang dianalisis bersifat time series.

Toko Nurnani, terletak di Jl. Merdeka No. 10, Ngunut-Tulungagung merupakan salah satu toko yang selalu ramai dengan barang dagangan yang dijual secara grosiran (reseller) ataupun eceran. Toko ini dikelola oleh Bu Nurnani sendiri untuk manajemen barang dagangannya. Kesulitan yang dialami oleh beliau ketika banyaknya kebutuhan dari barang yang diminta pelanggan, namun ketika barang tersebut dibeli ternyata malah menimbulkan kerugian. Penyebab utamanya adalah terlalu banyak restock barang pada salah satu jenis barang dagangan saja, sementara barang dagangan lainnya luput dari perhatian. Perlu adanya proses kontrol yang baik untuk restock barang, salah satunya yang peneliti tawarkan disini adalah menggunakan prediksi restock barang dagangan menggunakan single exponential smoothing.

\section{METODE}

\section{Forecasting}

Pada konsep pengenalan pola terdapat metode peramalan (forecasting) yang digunakan untuk memprediksi sesuatu data yang mendatang. Dapat diartikan juga peramalan sebagai ilmu pengetahuan yang digunakan untuk memprediksi peristiwa mendatang berdasarkan masa lalu[1]. Peramalan diperlukan karena kesenjangan waktu antara kesadaran untuk mengambil suatu kebijakan baru. Makin panjangnya perbedaan waktu, maka peran peramalan sangatlah penting. Utamanya untuk menentukan kapan terjadinya suatu peristiwa sehingga dapat diantisipasi sebelum terjadi. Dalam hubungannya dengan waktu, peramalan dibedakan menjadi 3 kelompok yaitu jangka panjang (2 sampai 10 tahun), jangka menengah (1 sampai 24 bulan) dan jangka pendek (1 sampai 5 minggu)[2].

Terdapat dua kelompok untuk melakukan peramalan yakni peramalan dengan metode kualitatif dan metode peralaman kualitatif[3]. Kedua kelompok tersebut menghasilkan peramalan secara kuantitatif, yang membedakan adalah cara peramalannya. Metode kuantitatif berdasarkan model matematik yang memproyeksikan data masa lalu untuk memberikan kesimpulan pada masa mendatang. Sedangkan metode kualitatif berdasarkan pertimbangan manusia (human judgement) dari pengalamannnya. Forecasting kebanyakan menggunakan data time series untuk meramalkan prediksi data di masa mendatang[2]. Data time series ini dilihat sebagai suatu representasi dari realisasi suatu variabel random yang mempunyai interval waktu yang sama dan diamati pada suatu periode tertentu[4].

\section{Single Exponential Smoothing}

Metode peramalan yang digunakan dalam penelitian ini adalah metode pemulusan exponensial tunggal (single exponential smoothing). Ciri dari metode ini adalah posisi data yang naik turun di sekitar nilai rata-ratanya yang tetap, tidak memiliki trend atau pola pertumbuhan konsisten[5]. Pada persamaan (1) ditunjukkan cara menghitung peramalannya. Metode ini memberikan sebuah pembobotan eksponensial rata-rata bergerak dari semua nilai observasi sebelumnya. SES tidak dipengaruhi oleh trend maupun musim. Untuk meramalkan nilai periode berikutnya, diperlukan data permintaan dari periode sebelumnya dan peramalan periode sebelumnya[6].

$$
\begin{aligned}
& S_{t}=\alpha X_{t}+(1-\alpha) F_{t-1} \\
& \text { Keterangan: } \\
& S_{t} \quad=\text { Peramalan untuk periode } \mathrm{t} \\
& X_{t} \quad=\text { Nilai aktual pada waktu ke-t } \\
& F_{t-1}=\text { Peramalan pada waktu t } \\
& \alpha \quad=\text { Parameter exponential dengan nilai antara } 0 \text { sampai } 1
\end{aligned}
$$




\section{Pengumpulan Data}

Pada tahap ini penulis melakukan pengumpulan data di Toko Nurnani, NgunutTulungagung. Dalam pengumpulan data ini dilakukan beberapa teknik, adapun teknik pengumpulan data yang dilakukan sebagai berikut:

1. Observasi

Untuk sampling data yang digunakan ada 2 jenis barang yang ditunjukkan pada Tabel 1. Data tersebut dipantau jumlah keluarnya mulai bulan April sampai September 2021.

Tabel 1. Sampling Data

\begin{tabular}{ccccc}
\hline No. & Nama Barang & Kategori & Brand & Satuan \\
\hline 1 & Beras Koi $5 \mathrm{~kg}$ & Beras & Ikan Koi & $\mathrm{kg}$ \\
2 & Minyak Bimoli $900 \mathrm{ml}$ & Minyak Goreng & Bimoli & liter \\
\hline
\end{tabular}

2. Studi Pustaka

Teknik pengumpulan studi pustaka dilakukan dengan mempelajari beberapa topik yang berhubungan dengan penelitian ini. Referensi sumber yang digunakan berasal dari buku, jurnal, internet, prosiding dan sebagainya. Untuk menguji akurasi dari peramalan single exponential smoothing, peneliti menggunakan metode MSE (Mean Squared Error). Pada MSE, masing-masing kesalahan atau sisa dikuadratkan, kemudian dijumlahkan dan ditambahkan dengan jumlah observasi[7]. Pendekatan tersebut mengatur kesalahan peramalan yang besar karena kesalahan-kesalahannya dikuadratkan. MSE memberikan ketelitian yang lebih baik daripada MAD sehingga banyak dipakai dalam optimalisasi pembobotan[8]. Perhitungan untuk MSE ditunjukkan pada persamaan (2).

MSE $=\frac{1}{n} \sum_{t=1}^{n}|A t-F t|^{2}$

Keterangan:

$$
\begin{array}{ll}
\text { At } & =\text { nilai aktual } \\
\text { Ft } & =\text { nilai hasil peramalan } \\
n & =\text { jumlah data }
\end{array}
$$

\section{Jenis Penelitian}

Penelitian ini menggunakan metode R\&D (Research and Development), dimana metode penelitian ini akan menghasilkan produk tertentu, dan menguji efektivitas dari produk tersebut[9]. Tujuan penelitian R\&D adalah menginformasikan proses pengambilan keputusan sepanjang pengembangan dari suatu produk menjadi berkembang dan kemampuan pengembang untuk menciptakan berbagai hal dari jenis ini pada situasi ke depan[10]. Pada penelitian ini hanya menggunakan 6 alur saja yang sudah dimodifikasi dari R\&D pada biasanya. Pada Gambar 1 ditunjukkan langkah R\&D-nya. Flowchart sistem digunakan untuk menunjukkan alur kerja dari penelitian ini dimana sistem secara keseluruhan menjelaskan prosedur urutannya. Berikut pada Gambar 2 ditunjukkan alur mengenai aplikasi prediksi stock barang dagangan pada penelitian yang diusulkan.

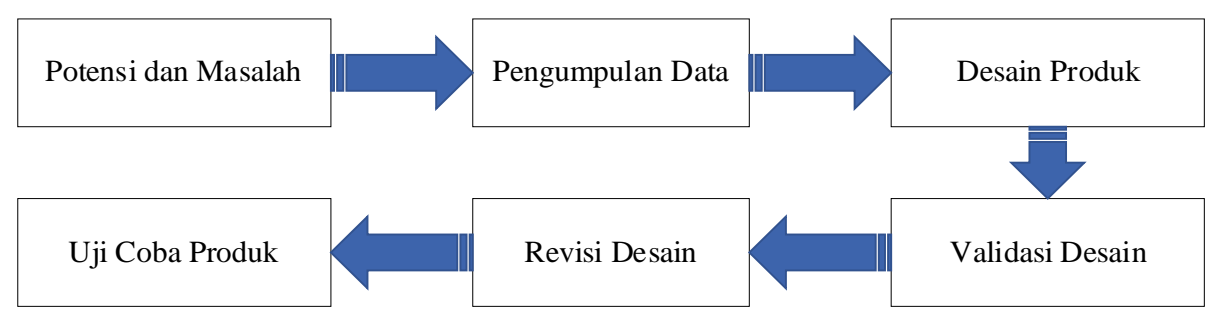


Gambar 1. Langkah Modifikasi R\&D Yang Digunakan

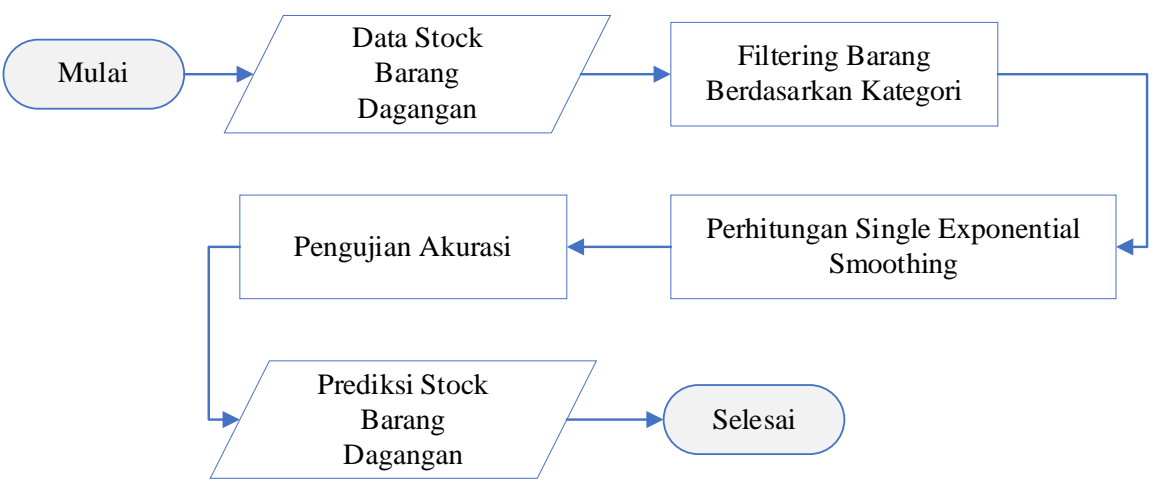

Gambar 2. Flowchart Aplikasi Peramalan Menggunakan Single Exponential Smoothing

\section{HASIL DAN PEMBAHASAN}

Berdasarkan flowchart Gambar 2, tahapan awal adalah mengumpulkan data penjualan Beras Koi $5 \mathrm{~kg}$ dan Minyak Bimoli $900 \mathrm{ml}$ pada selang waktu 01 April 2021 sampai 14 September 2021. Setiap dua minggu sekali dilakukan perhitungan dari penjualan barang tersebut. Untuk data aktual penjualan dari Beras Koi dan Minyak Bimoli ditunjukkan pada Tabel 2 dan Tabel 3.

Tabel 2. Data Aktual Penjualan Beras Koi $5 \mathrm{~kg}$

\begin{tabular}{clcc}
\hline No. & \multicolumn{1}{c}{ Tanggal/Bulan } & Periode & Aktual \\
\hline 1 & $01-$ 14 April 2021 & 0 & 12 \\
2 & 15 - 30 April 2021 & 1 & 15 \\
3 & 01 - 14Mei 2021 & 2 & 14 \\
4 & 15 - 31 Mei 2021 & 3 & 15 \\
5 & 01 - 14 Juni 2021 & 4 & 12 \\
6 & 15 - 30 Juni 2021 & 5 & 14 \\
7 & 01 - 14 Juli 2021 & 6 & 17 \\
8 & 15 - 31 Juli 2021 & 7 & 18 \\
9 & $01-$ 14 Agustus 2021 & 8 & 20 \\
10 & $15-31$ Agustus 2021 & 9 & 15 \\
11 & $01-$ 14 Sept 2021 & 10 & 18 \\
\hline
\end{tabular}

Tabel 3. Data Aktual Penjualan Minyak Bimoli $900 \mathrm{ml}$

\begin{tabular}{clcc}
\hline No. & \multicolumn{1}{c}{ Tanggal/Bulan } & Periode & Aktual \\
\hline 1 & 01 - 14 April 2021 & 0 & 4 \\
2 & 15 - 30 April 2021 & 1 & 6 \\
3 & 01 - 14Mei 2021 & 2 & 4 \\
4 & 15 - 31 Mei 2021 & 3 & 8 \\
5 & 01 - 14 Juni 2021 & 4 & 6 \\
6 & 15 - 30 Juni 2021 & 5 & 7 \\
7 & 01 - 14 Juli 2021 & 6 & 9 \\
8 & 15 - 31 Juli 2021 & 7 & 10 \\
9 & 01 - 14 Agustus 2021 & 8 & 9 \\
10 & 15 - 31 Agustus 2021 & 9 & 10 \\
11 & $01-$ 14 Sept 2021 & 10 & 11 \\
\hline
\end{tabular}




\section{Beras Koi 5 kg}

Dengan menggunakan data aktual tersebut, bisa diramalkan data penjualan di tanggal 15 September 2021 sampai 30 September 2021 dengan menggunakan peramalan single exponential smoothing dan memilih MSE dengan nilai terkecil. Dari Tabel 4, diketahui hasil peramalan di kolom Ft berdasarkan data aktual At. Didapatkan total nilai error absolut kuadrat adalah 78,9413653. Untuk menghitung nilai MSE, maka nilai error absolut kuadrat dibagi dengan $\mathrm{n}$, dimana $\mathrm{n}$ bernilai 11 sehingga menghasilkan nilai MSE 7,17648775. Untuk nilai alpha yang digunakan ada 3 macam yaitu 0,2, 0,4 dan alpha dari hasil estimasi sistem. Nilai alpha hasil estimasi sistem ini di-generate secara otomatis oleh sistem yang memungkinkan nilai forecasting-nya mendekati data aktual. Pada Tabel 5 dan Tabel 6 ditunjukkan hasil dari perhitungan alpha 0,4 dan estimasi.

Tabel 4. Perhitungan Ft dan MSE Beras Koi $5 \mathrm{~kg}$ untuk alpha $=0,2$

\begin{tabular}{clcccccc}
\hline No. & Tanggal-Bulan & Periode & At & Ft & Error & Error Abs & Error Abs`2 \\
\hline 1 & 01 - 14 April 2021 & 0 & 12 & 12,2000 & $-0,200$ & 0,2 & 0,04 \\
2 & 15 - 30 April 2021 & 1 & 15 & 12,1600 & 2,840 & 2,84 & 8,0656 \\
3 & 01 - 14 Mei 2021 & 2 & 14 & 12,7280 & 1,272 & 1,272 & 1,617984 \\
4 & 15 - 31 Mei 2021 & 3 & 15 & 12,9824 & 2,018 & 2,0176 & 4,07070976 \\
5 & 01 - 14 Juni 2021 & 4 & 12 & 13,3859 & $-1,386$ & 1,38592 & 1,92077425 \\
6 & 15 - 30 Juni 2021 & 5 & 14 & 13,1087 & 0,891 & 0,891264 & 0,79435152 \\
7 & 01 - 14 Juli 2021 & 6 & 17 & 13,2870 & 3,713 & 3,713011 & 13,7864507 \\
8 & 15 - 31 Juli 2021 & 7 & 18 & 14,0296 & 3,970 & 3,970409 & 15,7641476 \\
9 & 01 - 14 Agustus 2021 & 8 & 20 & 14,8237 & 5,176 & 5,176327 & 26,7943612 \\
10 & 15 - 31 Agustus 2021 & 9 & 15 & 15,8589 & $-0,859$ & 0,858904 & 0,73771574 \\
11 & $01-$ 14 Sept 2021 & 10 & 18 & 15,6872 & 2,313 & 2,312849 & 5,3492705 \\
\hline & & & & & Total Error Abs^2 & 78,9413653 \\
& & & & & & MSE & 7,17648775 \\
\hline
\end{tabular}

Tabel 5. Perhitungan Ft dan MSE Beras Koi $5 \mathrm{~kg}$ untuk alpha $=0,4$

\begin{tabular}{clcccccc}
\hline No. & Tanggal-Bulan & Periode & At & Ft & Error & Error Abs & Error Abs`2 \\
\hline 1 & 01 - 14 April 2021 & 0 & 12 & 12,2000 & $-0,200$ & 0,2 & 0,04 \\
2 & 15 - 30 April 2021 & 1 & 15 & 12,1200 & 2,880 & 2,88 & 8,2944 \\
3 & 01 - 14Mei 2021 & 2 & 14 & 13,2720 & 0,728 & 0,728 & 0,529984 \\
4 & 15 - 31 Mei 2021 & 3 & 15 & 13,5632 & 1,437 & 1,4368 & 2,06439424 \\
5 & 01 - 14 Juni 2021 & 4 & 12 & 14,1379 & $-2,138$ & 2,13792 & 4,57070193 \\
6 & 15 - 30 Juni 2021 & 5 & 14 & 13,2828 & 0,717 & 0,717248 & 0,51444469 \\
7 & 01 - 14 Juli 2021 & 6 & 17 & 13,5697 & 3,430 & 3,430349 & 11,7672943 \\
8 & 15 - 31 Juli 2021 & 7 & 18 & 14,9418 & 3,058 & 3,058209 & 9,35264229 \\
9 & 01 - 14 Agustus 2021 & 8 & 20 & 16,1651 & 3,835 & 3,834926 & 14,7066574 \\
10 & 15 - 31 Agustus 2021 & 9 & 15 & 17,6990 & $-2,699$ & 2,699045 & 7,28484391 \\
11 & $01-$ 14 Sept 2021 & 10 & 18 & 16,6194 & 1,381 & 1,380573 & 1,90598181 \\
\hline & & & & & Total Error Abs^2 & 61,0313446 \\
& & & & & & MSE & 5,54830405 \\
\hline
\end{tabular}

Tabel 6. Perhitungan Ft dan MSE Beras Koi $5 \mathrm{~kg}$ untuk alpha estimasi = 0,46

\begin{tabular}{cccccccc}
\hline No. & Tanggal-Bulan & Periode & At & Ft & Error & Error Abs & Error Abs^2 \\
\hline 1 & $01-$ 14 April 2021 & 0 & 12 & 13,4070 & $-1,407$ & 1,407029 & 1,97973061 \\
2 & 15 - 30 April 2021 & 1 & 15 & 12,7577 & 2,242 & 2,242316 & 5,02798104 \\
3 & $01-$ 14Mei 2021 & 2 & 14 & 13,7925 & 0,207 & 0,207485 & 0,04305003
\end{tabular}




\begin{tabular}{|c|c|c|c|c|c|c|c|}
\hline 4 & 15 - 31 Mei 2021 & 3 & 15 & 13,8883 & 1,112 & 1,11173 & 1,23594359 \\
\hline 5 & 01 - 14 Juni 2021 & 4 & 12 & 14,4013 & $-2,401$ & 2,401334 & 5,76640498 \\
\hline 6 & 15 - 30 Juni 2021 & 5 & 14 & 13,2931 & 0,707 & 0,706884 & 0,49968499 \\
\hline 7 & 01 - 14 Juli 2021 & 6 & 17 & 13,6193 & 3,381 & 3,380656 & 11,428835 \\
\hline 8 & 15 - 31 Juli 2021 & 7 & 18 & 15,1795 & 2,820 & 2,82048 & 7,95510743 \\
\hline 9 & $01-14$ Agustus 2021 & 8 & 20 & 16,4812 & 3,519 & 3,518825 & 12,3821294 \\
\hline 10 & 15 - 31 Agustus 2021 & 9 & 15 & 18,1051 & $-3,105$ & 3,105117 & 9,64175158 \\
\hline 11 & $01-14$ Sept 2021 & 10 & 18 & 16,6721 & 1,328 & 1,327898 & 1,7633131 \\
\hline \multicolumn{7}{|c|}{ Total Error $\operatorname{Abs}^{\wedge} 2$} & 57,7239317 \\
\hline & & & & & & MSE & 5,24763016 \\
\hline
\end{tabular}

Setelah nilai MSE diperoleh maka dibandingkan dengan yang lainnya. Nilai MSE yang terendah akan digunakan nilai alpha-nya untuk meramalkan data penjulan Beras Koi $5 \mathrm{~kg}$ pada 15-30 September 2021. MSE nilai terkecil dari produk Beras Koi 5 kg yaitu 5,24763016 dengan alpha estimasi 0,46. Hal ini bisa dilihat juga dari grafik yang ditunjukkan Gambar 4, dimana trend untuk alpha 0,46 warna hijau yang paling mendekati data aktualnya (data asli). Dengan nilai alpha 0,46, kemungkinan penjualan Beras Koi $5 \mathrm{~kg}$ sekitar 17,284928, jika dibulatkan menjadi 17. Ada kemungkinan Beras Koi tersebut pada tanggal 15-30 September 2021 akan mengalami sedikit penuruan jika dibandingkan pada tanggal 01-14 September 2021.

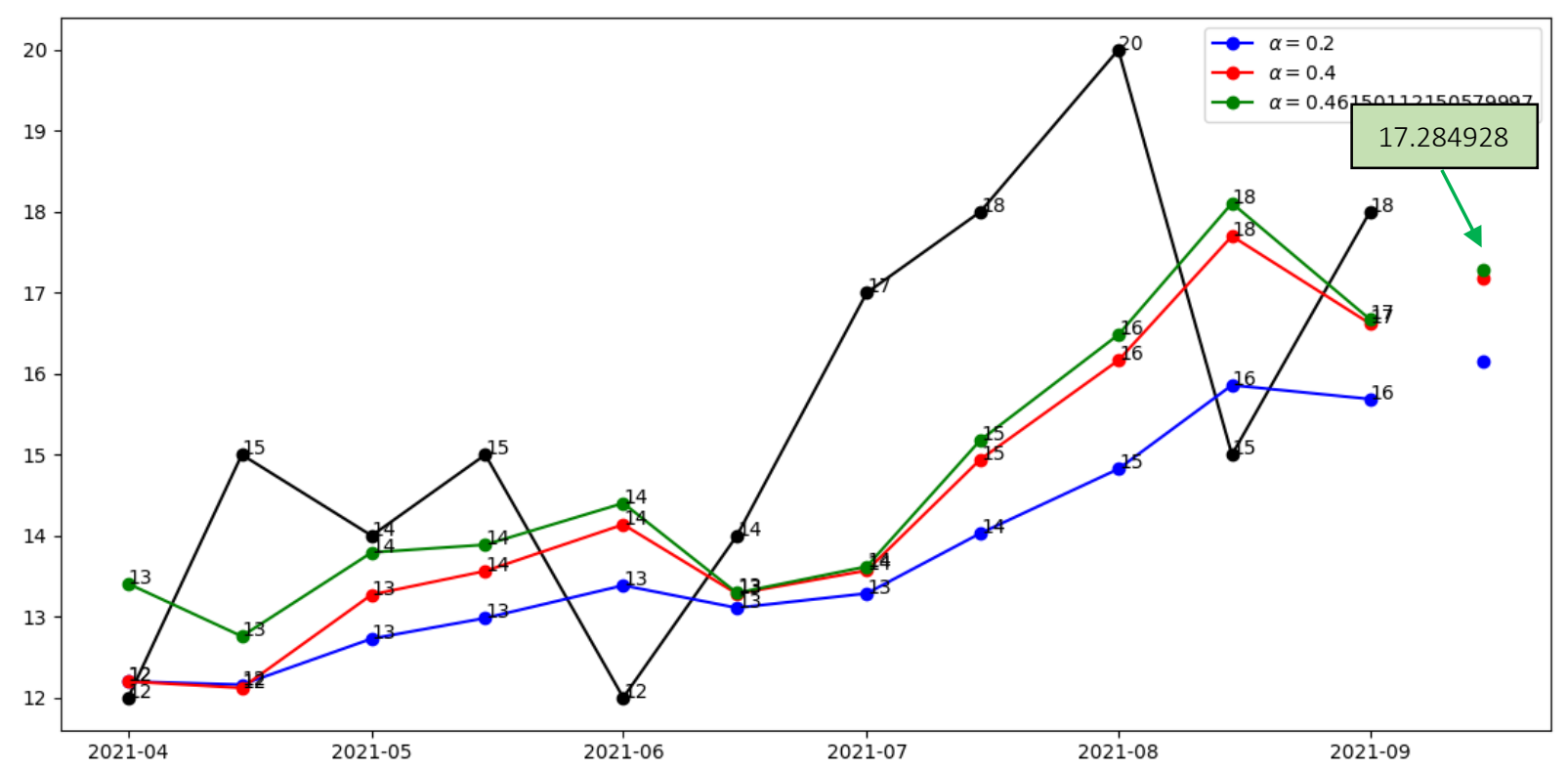

Gambar 3. Grafik Peramalan Beras Koi 5 kg

\section{Minyak Bimoli $900 \mathrm{ml}$}

Untuk Minyak Bimoli $900 \mathrm{ml}$, perhitungan dari exponential smoothing-nya ditunjukkan pada Tabel 7, 8, 9 berturut-turut dengan nilai alpha 0,2, 0,4, estimasi.

Tabel 7. Perhitungan Ft dan MSE Minyak Bimoli $900 \mathrm{ml}$ dengan alpha 0,2

\begin{tabular}{cccccccc}
\hline No. & Tanggal-Bulan & Periode & At & Ft & Error & Error Abs & Error Abs^2 \\
\hline 1 & $01-$ 14 April 2021 & 0 & 4 & 3,9333 & 0,0667 & 0,066667 & 0,00444449 \\
2 & 15 - 30 April 2021 & 1 & 6 & 3,9467 & 2,0533 & 2,053333 & 4,21617641 \\
3 & $01-$ 14Mei 2021 & 2 & 5 & 4,3573 & 0,6427 & 0,642667 & 0,41302087
\end{tabular}




\begin{tabular}{clcccccc}
4 & 15 - 31 Mei 2021 & 3 & 8 & 4,4859 & 3,5141 & 3,514133 & 12,3491307 \\
5 & $01-14$ Juni 2021 & 4 & 6 & 5,1887 & 0,8113 & 0,811307 & 0,65821905 \\
6 & 15 - 30 Juni 2021 & 5 & 7 & 5,3510 & 1,6490 & 1,649045 & 2,71934941 \\
7 & $01-$ 14 Juli 2021 & 6 & 9 & 5,6808 & 3,3192 & 3,319236 & 11,0173276 \\
8 & 15 - 31 Juli 2021 & 7 & 10 & 6,3446 & 3,6554 & 3,655389 & 13,3618687 \\
9 & $01-14$ Agustus 2021 & 8 & 9 & 7,0757 & 1,9243 & 1,924311 & 3,70297282 \\
10 & $15-$ 31 Agustus 2021 & 9 & 10 & 7,4606 & 2,5394 & 2,539449 & 6,44880122 \\
11 & $01-14$ Sept 2021 & 10 & 11 & 7,9684 & 3,0316 & 3,031559 & 9,19034997 \\
\hline & & & & Total Error Abs^2 & 64,0816614 \\
& & & & & & MSE & 5,82560558 \\
\hline
\end{tabular}

Tabel 8. Perhitungan Ft dan MSE Minyak Bimoli $900 \mathrm{ml}$ dengan alpha 0,4

\begin{tabular}{clcccccc}
\hline No. & \multicolumn{1}{c}{ Tanggal-Bulan } & Periode & At & Ft & Error & Error Abs & Error Abs^2 \\
\hline 1 & 01 - 14 April 2021 & 0 & 4 & 3,9333 & 0,0667 & 0,066667 & 0,00444449 \\
2 & 15 - 30 April 2021 & 1 & 6 & 3,9600 & 2,0400 & 2,04 & 4,1616 \\
3 & 01 - 14Mei 2021 & 2 & 5 & 4,7760 & 0,2240 & 0,224 & 0,050176 \\
4 & 15 - 31 Mei 2021 & 3 & 8 & 4,8656 & 3,1344 & 3,1344 & 9,82446336 \\
5 & 01 - 14 Juni 2021 & 4 & 6 & 6,1194 & $-0,1194$ & 0,11936 & 0,01424681 \\
6 & 15 - 30 Juni 2021 & 5 & 7 & 6,0716 & 0,9284 & 0,928384 & 0,86189685 \\
7 & 01 - 14 Juli 2021 & 6 & 9 & 6,4430 & 2,5570 & 2,55703 & 6,53840242 \\
8 & 15 - 31 Juli 2021 & 7 & 10 & 7,4658 & 2,5342 & 2,534218 & 6,42226087 \\
9 & 01 - 14 Agustus 2021 & 8 & 9 & 8,4795 & 0,5205 & 0,520531 & 0,27095252 \\
10 & 15 - 31 Agustus 2021 & 9 & 10 & 8,6877 & 1,3123 & 1,312319 & 1,72218116 \\
11 & $01-$ 14 Sept 2021 & 10 & 11 & 9,2126 & 1,7874 & 1,787391 & 3,19476659 \\
\hline & & & & & Total Error Abs^2 & 33,0653911 \\
& & & & & & MSE & 3,00594464 \\
\hline
\end{tabular}

Tabel 9. Perhitungan Ft dan MSE Minyak Bimoli $900 \mathrm{ml}$ dengan alpha estimasi = 0,704

\begin{tabular}{clcccccc}
\hline No. & \multicolumn{1}{c}{ Tanggal-Bulan } & Periode & At & Ft & Error & Error Abs & Error Abs^2 \\
\hline 1 & 01 - 14 April 2021 & 0 & 4 & 4,5699 & $-0,5699$ & 0,569887 & 0,32477119 \\
2 & 15 - 30 April 2021 & 1 & 6 & 4,1685 & 1,8315 & 1,831516 & 3,35445086 \\
3 & 01 - 14Mei 2021 & 2 & 5 & 5,4585 & $-0,4585$ & 0,458522 & 0,21024242 \\
4 & 15 - 31 Mei 2021 & 3 & 8 & 5,1356 & 2,8644 & 2,86444 & 8,20501651 \\
5 & 01 - 14 Juni 2021 & 4 & 6 & 7,1531 & $-1,1531$ & 1,153143 & 1,32973878 \\
6 & 15 - 30 Juni 2021 & 5 & 7 & 6,3409 & 0,6591 & 0,659079 & 0,43438513 \\
7 & 01 - 14 Juli 2021 & 6 & 9 & 6,8051 & 2,1949 & 2,194853 & 4,81737969 \\
8 & 15 - 31 Juli 2021 & 7 & 10 & 8,3511 & 1,6489 & 1,648897 & 2,71886132 \\
9 & 01 - 14 Agustus 2021 & 8 & 9 & 9,5125 & $-0,5125$ & 0,512512 & 0,26266855 \\
10 & 15 - 31 Agustus 2021 & 9 & 10 & 9,1515 & 0,8485 & 0,848478 & 0,71991492 \\
11 & 01 - 14 Sept 2021 & 10 & 11 & 9,7492 & 1,2508 & 1,250848 & 1,56462072 \\
\hline & & & & & Total Error Abs^2 & 23,9420501 \\
& & & & & & MSE & 2,17655001 \\
\hline
\end{tabular}

Dari hasil penelitian yang dilakukan, nilai MSE terkecil pada produk Minyak Bimoli $900 \mathrm{ml}$ adalah 2,17655001 dengan alpha estimasi 0,704. Ditunjukkan pada Gambar 4, terlihat bahwa garis warna hijau dengan alpha 0,704 yang paling mendekati nilai aslinya (garis warna hitam). Jadi kemungkinan bisa diramalkan pada tanggal 15-30 September 2021, penjualan Minyak Bimoli $900 \mathrm{ml}$ akan turun menjadi 10,630193 jika dibulatkan menjadi 10. 


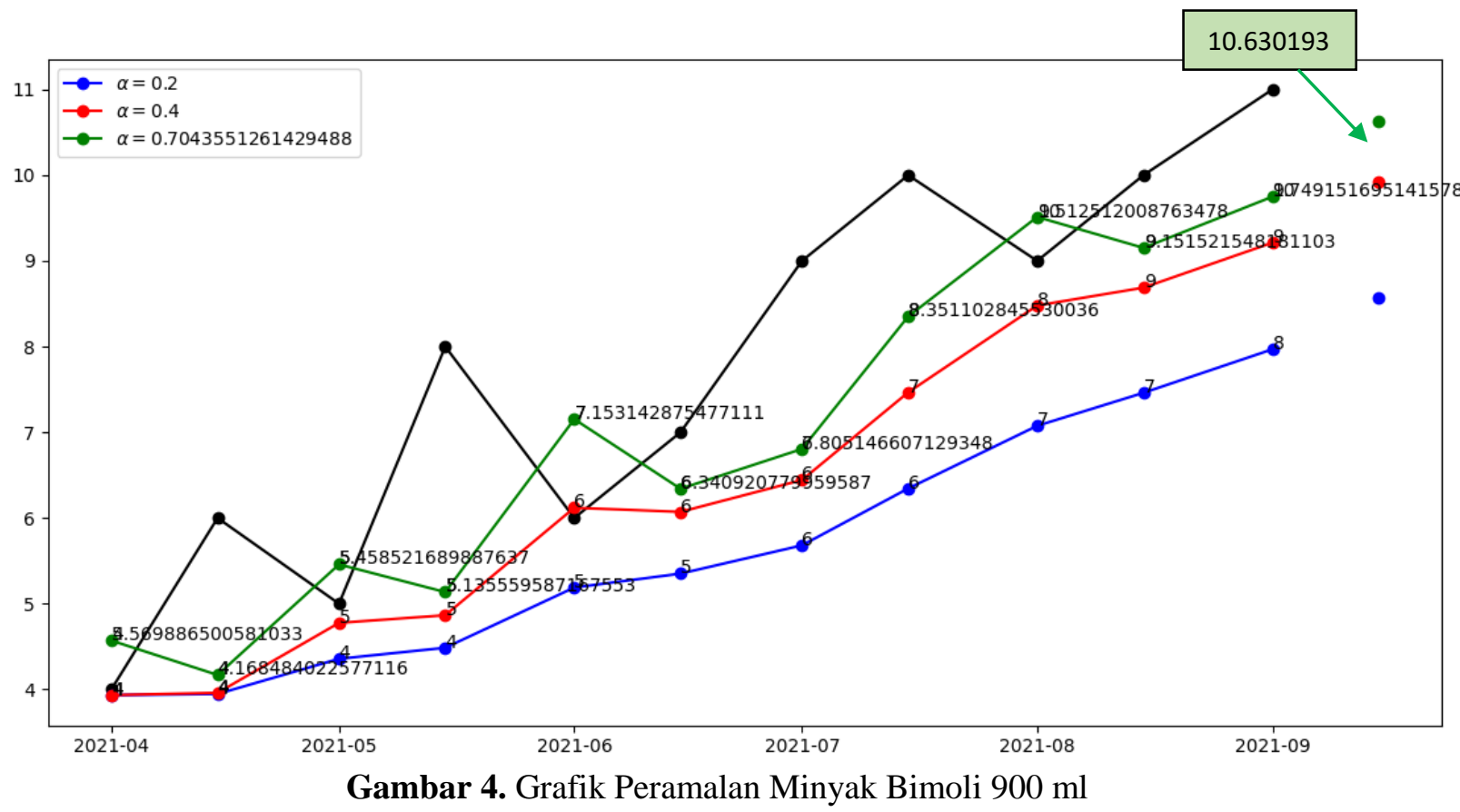

\section{SIMPULAN DAN SARAN}

Dari hasil uji coba pada penelitian ini, didapatkan nilai MSE terkecil untuk produk Beras Koi $5 \mathrm{~kg}$ sebesar 5,24763016 dengan alpha 0,46. Sedangkan nilai MSE terkecil untuk produk Minyak Bimoli $900 \mathrm{ml}$ 2,17655001 dengan alpha 0,704. Nilai MSE terkecil digunakan sebagai indikator terbaik untuk peramalan produk terkait pada periode berikutnya. Penjualan produksi Beras Koi $5 \mathrm{~kg}$ dan Minyak Bimoli $900 \mathrm{ml}$ akan mengalami penurunan di tanggal 15-30 September 2021 dari hasil peramalan. Data yang digunakan pada penelitian ini masih terbatas sekitar bulan April sampai September, sehingga nilai peramalan dari data time series tersebut kurang begitu maksimal. Penelitian ke depannya, mungkin bisa menggunakan metode yang lebih baik lagi dimana mampu meramalkan suatu nilai berdasarkan input data time series yang singkat.

\section{DAFTAR PUSTAKA}

[1] J. Heizer and B. Render, Manajemen Operasi : Manajemen Keberlangsungan dan Rantai Pasokan. Jakarta: Salemba Empat, 2015.

[2] A. Nurlifa and S. Kusumadewi, "Sistem Peramalan Jumlah Penjualan Menggunakan Metode Moving Average Pada Rumah Jilbab Zaky," Jurnal INOVTEK Polbeng Seri Informatika, vol. 2, pp. 18-25, Juni 20172017.

[3] H. Yulius and I. Yetti, "Peramalan Kebutuhan Manajemen Logistik Pada Usaha Depot Air Minum Isi Ulang Al-Fitrah," Jurnal Edik Informatika, vol. 1, pp. 5-14, 2017.

[4] S. Nawangwulan and D. Angesti, "Analiss Time Series Metode Winter Jumlah Penderita Gastroenteritis Rawat Inap Berdasarkan Data Rekam Medis di RSUD Dr.Soetomo Surabaya," Jurnal Manajemen Kesehatan STIKES Yayasan RS. Dr. Soetomo, vol. 2, pp. 17-32, 2016.

[5] H. Himawan and P. D. Silitonga, "Comparison Of Forecasting Accuracy Rate Of Exponential Smoothing Method on Admission of New Students," Journal of Critical Reviews, vol. 7, no. 2, 2020.

[6] K. F. Pinontoan, "Pemodelan Single Exponential Smoothing (SES) Dan Integer Autoregressive (INAR) Pada Peramalan Permintaan Intermittent," Jurnal Sains dan Teknologi, vol. 2, pp. 141-146, 2018. 
[7] A. Lusiana and P. Yuliarty, "Penerapan Metode Peramalan (Forecasting) pada Permintaan Atap di PT X," Jurnal Teknik Industri ITN Malang, 2020.

[8] S. M. Robial, "Perbandingan Model Statistik Pada Analisis Metode Peramalan Time Series (Studi Kasus: PT. Telekomunikasi Indonesia, TBK Kandatel Sukabumi)," Jurnal Ilmiah SANTIKA, vol. 8, 2018.

[9] B. Saputro, Manajemen Penelitian Pengembangan (Research \& Development) Bagi Penyusun Tesis dan Disertasi. Yogyakarta: Aswaja Pressindo, 2017.

[10] Sugiyono, Metode Penelitian Kuantitatif Kualitatif dan R\&D. Bandung: PT. Alfabet, 2016. 